\title{
Concession as a state investment policy tool
}

\author{
Inna Shor ${ }^{1 *}$, Viktor Pushkarev ${ }^{2}$, Ekaterina Tokareva ${ }^{3}$, and Olga Shepeleva ${ }^{4}$ \\ ${ }^{1}$ Volgograd State University, Prospect Universitetsky, 100, Volgograd, Russia, ShorIM@volsu.ru \\ 2 Plekhanov Russian University of Economics, Stremyanny lane, 36, Moscow, Russia, vvp77r@rambler.ru \\ ${ }^{3}$ Leningrad state University named by A. S. Pushkin, St. Petersburg sh., 10, St. Petersburg, Russia, tokareva.e.v@bk.ru \\ ${ }^{4}$ Leningrad state University named by A. S. Pushkin, St. Petersburg sh., 10, St. Petersburg, Russia, shepeleva.o.r@mail.ru
}

\begin{abstract}
Russian Federation's competitiveness is largely interconnected with the state investment policy's development level. However, the need for investments in high-quality infrastructure, on the one hand, and corresponding budget funds deficit, on the other hand, highlight the problem of the state and business entities' cooperation by means of concession. At the same time there are many barriers, which hinder the concession's consecutive development. That is why the research goal includes the elaboration of measures, aimed at the effective application of a concession as a tool of state investment policy. The systematic approach and a set of scientific measures, including observation, expert assessment, statistical data processing, analysis and comparison have been applied in the study. As a result, the research authors define the following growth areas of a concession: legal normative (normative consolidation of the concession's development strategies and programmes, quality improvement of the methodological and legal concession projects elaboration), production organizational (quality improvement of territorial planning when proposing concessional agreements, the application of a complex approach to concession's facilities' modernization and etc.) and economic (broadening the spectrum of budgetary and non-budgetary tools used for financing concessional projects, elaboration of reasonable requirements to guarantee exposure according to the concessional agreement and etc.).
\end{abstract}

\section{Introduction}

These days it is essential to ensure effective cooperation between the state and business entities with the help of the public-private partnership toolset in order to implement socially useful projects, primarily connected with building various infrastructure facilities. At the same time it is worth mentioning that private investments are of key significance, while public funding is auxiliary and promotes the attraction and effective treatment of the business entities' investments. [1].

Only of the most widespread form of public-private partnership is a concession, which allows funding infrastructure facilities at the expense of private investments in terms of the insufficient state budget [2]. One of the reasons, why business entities participate in a concession is that they get an opportunity to increase their capital by funding socially useful projects, and they also enhance their competitiveness [3].

\section{Problem Statement}

The analysis of concessions use has elicited a number of barriers, hindering their development, which are legalnormative, organizational, production and economic [3]. But still the elaboration of practical measures aimed at creating an effective concession remains debatable [4].
The cooperation between the state and business entities is insufficiently scientifically substantiated, that is why it is worth mentioning the topicality of studying a concession, as a tool of state investment policy .

\section{Research Questions}

The keys to understanding scientific and practical aspects of a concession as a tool of state investment policy are as follows:

- What is the substance of a concession as a state investment policy tool?

- Which features are characteristic of a concession if speaking about the public utility infrastructure system, which belongs to the municipality urban district of Volgograd?

- What are the challenges and growth points in the development of a concession as a state investment policy tool?

\section{Purpose of the Study}

The research purpose is to elaborate the measures aimed at ensuring the effective application of a concession as a state investment policy tool.

\footnotetext{
* Corresponding author: ShorIM@volsu.ru
} 


\section{Research Methods}

The study's methodology has been formed according to the scientific theory in the field of public-private partnership in general and concession in particular. The systematic approach and a set of scientific measures, including observation, expert assessment, statistical data processing, generalization, analysis and comparison have been applied in the study.

\section{Findings}

The creation and reconstruction of social, cultural and other state facilities are the top-priority goals of the Russian socio-economic development. However, in times of state budget deficit there are certain problems in achieving these goals. That is why the issues of applying a concession, as a public and private partnership priority form, are highly urgent [5].

The core of a concession is the relation between the state (the concession grantor) and a legal or individual entity concessionaire, which arises in the course of ensuring by the concession grantor to the concessionaire the rights for using the state property under an agreement on a paid and return basis as well as the rights for carrying out the activities, comprising the state monopoly [6]. Correspondingly, the following features characterize a concession:

- By the goal - state property reconstruction; construction of a concession agreement facility, which will belong to the state;

- $\quad$ By the investment object - state property and monopoly activities; intended purpose alternation and pledge ban; investments object's return character; laying the risk of damage or the investments object's accidental destruction on the concessionaire unless otherwise specified;

- $\quad$ By the investment subjects and their interrelations - a concession grantor and concessionaire; concession grantor's compensation of a concessionaire's part of expenses; a concessionaire's commission fee payment to the state's budget; distribution of risks between a concession grantor and concessionaire [7].

Thus, it can be mentioned that a concession's advantages for the state deal with solving socioeconomic tasks at the business entities' expense, with preserving the initial purpose and provision of the state property's effective use, as well as with the opportunity of getting the rights for the state's movables and immovables, created by the concessionaire for ensuring the activity stated in the concession agreement [8]. Although, there some drawbacks in a concession from the state's side, which include the state's movables and immovables (which have been acquired during the realization of a concession agreement and in case the agreement does not imply this property's transfer to the state's ownership) transfer into the concessionaire's ownership. Another drawback is the concessionaire's acquisition of rights for the production and profit, received in the course of business activity, stipulated by the concession agreement. In return, from the investment subjects' side, one of the concession's main strengths is stimulating the investment activity, which leads to the profitability increase and competitiveness and sustainability enhancement. However, there are some drawbacks as well, which deal with high control pressure from the state under the concession agreement [9].

Taking into account the data of the National Association of Concessionaires and Long-Term Infrastructure Investors, it is worth noting that from 2009 till 2019, 277 concession agreements with a total volume of investment obligations of 1.754 trillion rubles, were concluded in Russia. Out of this investment amount 476 billion rubles is the volume of direct government obligations intended for creating and modernizing the infrastructure and 1.278 trillion rubles is the volume of investment obligations of the concessionaire. The largest numbers of concession agreements were concluded at the municipal level, which is 183 projects or 66 percent out of the total. 81 concession agreements, or 29 percent out of the total, were concluded at the sub-federal level, whereas 13 concession agreements or 5 percent out of the total were concluded at the federal level. At the same time, in terms of the investment obligations volume, concession agreements concluded at the sub-federal and federal levels occupy approximately equal shares - 41 percent each. The volume of investment commitments for municipal projects is 353.6 billion rubles or 18 percent of the total volume of market. The largest number of concession agreements were concluded in the field of utilities and communal services - 162 projects or 59 percent out of the total number of concession agreements. In terms of the investment obligations volume, the transport sector occupies the leading position - which is $1,457.2$ billion rubles, or 77 percent out of the total investment obligations volume under concession agreements.

An example of a unique experience in the implementation of a concession not only on the national but also on the world level is the concession agreement, regarding the facilities' infrastructure system, owned by the municipality Urban District of Hero City Volgograd. The concession agreement is concluded between the Volgograd City Administration, Municipal Unitary Enterprise "Volgograd City Vodokanal" and "Water Supply Concessions" LLC. Within the framework of the concession agreement, the "Water Supply Concessions" LLC concessionaire ensures the design, construction, reconstruction and commissioning of water supply and sewerage facilities and the achievement of the planned performance indicators established in the concession agreement. In turn, the concession grantor must establish a tariff taking into account the concessionaire's reasonable expenses, long-term regulation parameters established by the agreement, investment measures and the execution period. Municipal Unitary Enterprise "Volgograd City Vodokanal" continues its activities as an operator of water supply and wastewater disposal facilities. In July 2015, the "Water Supply Concessions" LLC received the status of a guaranteed supplier in the field of water supply and wastewater disposal on the territory of the municipality Urban District of Hero City 
Volgograd. And at the end of 2015, this concession agreement was recognized as the largest investment deal in Europe in the field of utilities and communal services.

This concession agreement has been implemented for 30 years. The volume of investments in the project reaches 58 billion rubles. This is the largest concession agreement in the field of utilities and communal services in Russia. The project model implemented involves attracting institutional investors' funds, i.e. non-state pension funds, through the mechanism of concession obligations. The "Water Supply Concessions" LLC represents the interests of investors, providing the unconditional return on investment by achieving the investment program implementation effect, as well as by reducing costs. The investment program includes several sets of activities:

- construction, modernization and reconstruction of facilities of centralized water supply and (or) water disposal systems in order to connect capital construction facilities;

- construction of new facilities for centralized water supply and sewerage systems not related to the connection of new capital construction facilities;

- construction of new facilities for centralized water supply and sewerage systems, not related to the connection of new capital construction facilities (measures aimed at enhancing the environmental efficiency, achieving the planned reliability values, quality and energy efficiency of centralized water supply and (or) sewerage facilities;

- $\quad$ shutdown, conservation and dismantling of objects of centralized water supply and (or) sewerage systems.

The main reasons why the "Water Supply Concessions" LLC concluded a concession agreement with the municipality Urban District of Hero City Volgograd, regarding the communal infrastructure facilities, were the state of the utilities infrastructure system (centralized cold water supply and sewerage) on the territory municipality Urban District of Hero City Volgograd at the beginning (in 2015 the utilities infrastructure system was 80.4 percent deteriorated), low rates and volumes of network reconstruction and equipment modernization, a high level of network losses and a low degree of energy saving and energy efficiency. In the second half of 2015, about 720 thousand cubic metres of untreated wastewater was discharged into the soil and surface water, which caused great harm to the ecology of the region. At the same time, by the second half of 2016, the "Water Supply Concessions" LLC had completely eliminated the discharge of untreated wastewater into the soil and surface water. In addition, the loss of clean water was 46.2 percent, which was 94,557,054 cubic metres of the entire mass of water raised from the Volga River. At the same time, in the first half of 2017 the "Water Supply Concessions" LLC reduced the loss of clean water to 24.9 percent. In general, the actions taken by the "Water Supply Concessions" LLC to reconstruct and modernize the centralized water supply and sewerage networks positively influenced a number of key indicators reflecting the quality of water supply and sewerage.
Without diminishing the significance of the above presented results of the concession agreement implementation, it is necessary to highlight the regulatory, organizational, production and economic barriers that hinder further development of the concession both in the field of utilities and communal services and other infrastructural sectors of Russia. The legal-normative barriers are associated with imperfect legislation in the field of concession activities, low business entities' awareness about a concession's legal structures, business entities' low level of legal protection in the implementation of concession projects, and other [10]. Organizational and production barriers are reflected in an insufficient level of competence and experience in the sphere of implementing concession agreements, low quality or the absence of territorial planning documents when forming the proposals for concluding concession agreements, the lack of an integrated approach to modernizing concession facilities, and other [11]. Economic barriers are characterized by the economic instability, increased requirements to the amount of guarantees, insufficient development of the deferred payments mechanism under a concession agreement, and others [12].

\section{Conclusion}

The regulatory, organizational, production and economic nature can be traced not only in the barriers, but also in the growth points in the development of a concession as a tool of state investment policy. These growth points include:

- regulatory and legal growth points - normative consolidation of strategies and programs of the concession's development, methodological and legal development of concession projects quality improvement, increase of awareness of the legal structures of the concession and legal protection of concession activities' subjects;

- organizational and production growth points quality improvement of territorial planning in the formation of proposals for concluding concession agreements, application of an integrated approach to modernizing concession facilities, provision of organizational, technical and other kinds of support from the state, facilitation of measures promoting experience exchange in the sphere of concession projects implementation, personnel training and retraining in the field of concession activity;

- economic growth points - expansion of the toolset of budgetary funding (government guarantees, budget loans, targeted grants) and off-budget funding (loans, bonded loans, pension funds finance, insurance companies and other) of concession projects, development of reasonable requirements to the amount of guarantees and the mechanism of deferred payments under a concession agreement.

In the end, it should be noted that the formation of these growth points requires, firstly, the application of an integrated approach to creating an effective risk management system and ensuring high quality state 
support to concession projects. At the same time, the study emphasizes that while creating a concession agreement object, it is necessary to: assess all potential risks, draw up and update the matrix of risks and plans for resolving extraordinary situations and deviations from the initial plan in the process of implementing a concession project; create a multi-level system for the concession project implementation qualitative and quantitative parameters control [13]. Consequently, during the exploitation of the concession agreement object, it is important to create long-term partnership relations with contractors in all areas of activity; strict observance of technical regulations for the machinery and equipment operation, as well as safety and labor protection requirements [14], [15]. And, secondly, given that concession projects are long-term, which promotes business entities' stable development and predictable profitability, a high level of confidence in the concession system is crucial for making decisions on such long-term investments.

\section{References}

1. V. G. Varnavskii, The partnership between the government and the private sector (Nauka, Moscow, 2019)

2. S.S. Chernov, M.V. Filchenkova, Business. Education. Law 3 (40), 82-89 (2017)

3. O.V. Tarasova, Bulletin of the Novosibirsk state University of Economics and management 2, 71-84 (2019)

4. N.N. Kosinova, Bulletin of the Volgograd state agricultural University. Series 3, Economics. Ecology 3, 87-98 (2017)

5. V.V. Baranov, Property relations in the Russian Federation 9, 74-81 (2019)

6. V.A. Kabashkin, Public-private partnership: international experience and Russian perspectives (LLC "MIZ", Moscow, 2020)

7. I.M. Shor, Financial Analytics: problems and solutions 42, 38-48

8. A.A. Postnikova, Economics and business: theory and practice 1, 87-91 (2017)

9. D.M. Shor, I.M. Shor, Financial Analytics: problems and solutions 46 (328), 18-31 (2016)

10. N.L. Platonova, Law and Economics 1, 16-21 (2019)

11. N.N. Semenova, Economy. Taxes. Law 13 (3), 5969 (2020)

12. N.V. Kalinin, T.V. Medvedeva, G.A. Romitsyna, Economic Sciences 2, 53-56 (2018)

13. V.V. Karginova, Economics and management 1, 51-62 (2017)

14. V.A. Fursov, N.V. Lazareva, Bulletin of the North Caucasus Federal University 1 (52), 103-108 (2016)

15. A.G. Zeldner, Public-private partnership: theory, methodology and practice, (Institute of Economics of the Russian Academy of Sciences, Moscow, 2019) 